\title{
Comparative Study of Local Cements with Imported Class 'G' Cement at Different Temperatures for Oil Well Cementing Operations in Ghana
}

\section{Broni-Bediako $\mathrm{E}^{1 *}$, Joel $\mathrm{OF}^{2}$ and Ofori-Sarpong $\mathbf{G}^{3}$}

${ }^{1}$ Department of Petroleum Engineering, University of Mines and Technology, Ghana

${ }^{2}$ Centre for Petroleum Research and Training, Institute of Petroleum Studies, University of Port Harcourt, Nigeria

${ }^{3}$ Department of Mineral Engineering, University of Mines and Technology, Ghana

\begin{abstract}
The purpose of this research is to determine the suitability of local cements as an alternative to imported class $\mathrm{G}$ cement at different temperatures using oil well cement additives. Laboratory investigations on both local and imported cements to determine physical properties such as thickening time, fluid loss, compressive strength, free fluid and rheology were conducted at bottom hole circulating temperature of $27^{\circ} \mathrm{C}\left(80^{\circ} \mathrm{F}\right)$ and $66^{\circ} \mathrm{C}\left(150^{\circ} \mathrm{F}\right)$. The results indicated that locally manufactured cements are compatible with oil well cement additives at $80^{\circ} \mathrm{F}$ and $150^{\circ} \mathrm{F}$ and can be used as an alternative to imported class $\mathrm{G}$ cement in oil and gas well cementing operations. However, premature gelations of test results were phenomenal at $66^{\circ} \mathrm{C}\left(150^{\circ} \mathrm{F}\right)$ for the entire locally manufactured cements especially sample CEM B. Therefore, for local cements to be used effectively for cementing high temperature operations, stringent quality control during their manufacturing process is imperative.
\end{abstract}

Keywords: Compressive strength; Free fluid; Fluid loss; Portland cement; Rheology; Thickening time

\section{Introduction}

Oil well cementing is a vital operation for wellbore completion. It involves placing cement slurry from the surface to several thousands of feet below the surface of the earth [1]. The cement slurry used consists mainly of cement, water and performance-controlling additives [2]. High quality cement slurry will serve the production of oil economically and safely over the well's lifetime [3]. It will ensure the long-term durability of wellbore by providing a high-quality casing $[4,5]$ whereas poor quality of cement slurry may lead to remedial cementing and will increase the time and cost of cementing operation [6]. In oil well cementing, less error is tolerated as compared to conventional cementing work. Oil well cement slurry must therefore be carefully designed to meet a wide range of short term requirements such as a predictable thickening time (set time), low viscosity, low free fluid, adequate strength development, fluid loss control, etc., as well as certain long-term requirements such as thermal stability, resistance to downhole chemicals and mechanical integrity of the cement sheath $[7,8]$. Due to the important role of cement in oil and gas cementing operations, the oil industry purchases cements manufactured in accordance with American Petroleum Institute (API) specifications. This special class of cements is called oil well cements (OWCs).

In Ghana, oil well cement type class $G$ is used for the oil and gas wells cementing operations, and this cement is imported from other countries. There is no single oil well in Ghana that has been cemented with locally manufactured cement. According to Atiemo [9]. about $90 \%$ of cement in Ghana is consumed by the building sector whilst the remaining $10 \%$ is mainly consumed by the road sector for the construction of bridges, culverts, drains and pedestrian pavements among others. Cementing of oil well is a capital-intensive project, and the cost of getting the imported cement is quite enormous. This increases the demand for scarce foreign exchange and import dependency on the economy. This trend is expected to continue as cementing operation increases since there is no performance evaluation of locally manufactured cement for utilisation in oil and gas cementing operations in Ghana. The quest to evaluate the performance of local cements which are less expensive and available in contrast to foreign cements is very important and appropriate. This will, in no doubt, provide home-base technological advancement, significant logistical improvement, substantial cost saving, and overall, help meet up with the local content aspiration. This paper focuses mainly on evaluating the suitability of three locally manufactured cements and imported class $\mathrm{G}$ cement mixed with different percentage of cement additives at different temperatures.

\section{Materials and Methods}

\section{Materials}

Three brands of cement available on the Ghanaian market and commonly used by Ghanaians for construction purposes were purchased from retail outlets in Aflao in the Volta Region, Buipe in Northern Region and Tarkwa in the Western Region. The imported sample (class G cement) was obtained from Schlumberger Oil Services Company in Ghana. Fresh water was used for the cement slurry formation. Additives such as defoamer, accelerator, fluid loss additive and retarder were obtained from a service company in Port Harcourt, Nigeria. The additives used in the cement composition were selected based on the test pressure and temperature conditions. Accelerator was employed to reduce the setting time of cement slurry at ambient pressure and temperature. The retarder and fluid loss additive were used to respectively increase the setting time and control fluid loss of the cement slurry at high pressures and temperatures. Defoamer was

*Corresponding author: Broni-Bediako E, Department of Petroleum Engineering, University of Mines and Technology, Ghana, Tel: +233 243052455; E-mail: ebroni-bediako@umat.edu.gh

Received June 10, 2015; Accepted June 30, 2015; Published July 12, 2015

Citation: Broni-Bediako E, Joel OF, Ofori-Sarpong G (2015) Comparative Study of Local Cements with Imported Class ' $G$ ' Cement at Different Temperatures for Oil Well Cementing Operations in Ghana. J Pet Environ Biotechnol 6: 233. doi:10.4172/2157-7463.1000233

Copyright: (c) 2015 Broni-Bediako E, et al. This is an open-access article distributed under the terms of the Creative Commons Attribution License, which permits unrestricted use, distribution, and reproduction in any medium, provided the original author and source are credited. 
Citation: Broni-Bediako E, Joel OF, Ofori-Sarpong G (2015) Comparative Study of Local Cements with Imported Class 'G' Cement at Different Temperatures for Oil Well Cementing Operations in Ghana. J Pet Environ Biotechnol 6: 233. doi:10.4172/2157-7463.1000233

Page 2 of 7

also used to remove slurry foam during formulation.

\section{Experimental design}

Laboratory experiments were performed on local cement slurry to determine the potential of locally manufactured cement mixed with oil well cement additives at $27^{\circ} \mathrm{C}\left(80^{\circ} \mathrm{F}\right)$ and $66^{\circ} \mathrm{C}\left(150^{\circ} \mathrm{F}\right)$. The cement slurry and specimen preparation were carried out by closely following API Specification 10A. The physical properties were determined by closely following API Specification $10 \mathrm{~A}$ and API Recommended Practice 10B $[10,11]$. The physical properties tests conducted included thickening time, compressive strength, free fluid, fluid loss and rheology of the cement slurry. Three brands of locally manufactured cement (CEM A, CEM B, and CEM C) and imported class G cement (CEM G) were investigated at the two testing conditions for each of the cement samples (Table 1).

\section{Thickening time testing}

The results of the laboratory thickening time tests provide an indication of the length of time that cement slurry would remain pumpable [12]. That is, the time after initial mixing when the cement can no longer be pumped [13]. Consistency of cement slurry is expressed in Bearden units of consistency (Bc) [12]. The Thickening Time (TT) test was performed in a High-Pressure High-Temperature (HPHT) Consistometer that is usually rated at pressure up to 206.8 $\mathrm{MPa}(30000 \mathrm{psi})$ and temperatures up to $204^{\circ} \mathrm{C}\left(400^{\circ} \mathrm{F}\right)$. The cement slurry was mixed according to API procedures and then placed in a slurry cup into the consistometer for testing. The testing pressure and temperature were controlled to simulate the conditions the slurry will encounter in the well. The test concluded when the slurry reached a consistency considered unpumpable in the well. The maximum consistency during 15 minutes to 30 minutes after the initiation of the test and the time for the cement slurry to reach consistency of $100 \mathrm{Bc}$ were recorded $[10,11]$.

\section{Free fluid testing}

The intention of a free fluid test is to help determine the quantity of free fluid that will gather on the top of cement slurry between the time it is placed and the time it gels and sets up [14]. The cement slurries were preconditioned in a Model 165AT Atmospheric Consistometer for thirty minutes. The preconditioned slurry was remixed within 10 seconds and poured into a $500 \mathrm{cc}(500 \mathrm{ml})$ graduated flask according to API Specification 10A [11]. The mouth of the flask was sealed and then placed on a vibration free surface for 2 hours. The slurry was then examined for any free fluid on the top of the cement column. This free fluid was decanted and measured with a syringe to determine the percent of free water $(\varphi)$ based on the weight and the specific gravity of the cement using Equation (1).

$$
\varphi=\left(\mathrm{V}_{\mathrm{FF}}\right) \times \mathrm{S}_{\mathrm{g}} \times \frac{100}{\mathrm{~m}_{\mathrm{S}}}
$$

where $\mathrm{V}_{\mathrm{FF}}$ is the volume of free fluid collected (supernatant fluid), expressed in millilitres; $\mathrm{S}_{\mathrm{g}}$ is the specific gravity of the slurry, and $\mathrm{m}_{\mathrm{s}}$ is the initially recorded mass of the slurry in grams.

\section{Compressive strength testing}

Compressive strength is one of the properties used to test the reliability of cementing and is the ability of a material to withstand deformation when load is applied [15]. There are two common methods for determining the compressive strength of a cement slurry; non-destructive and destructive. Destructive method was employed in this research. The destructive test indicates how the cement sheath will withstand the differential pressures in the well. The main advantage with this type of method is that an exact value of compressive strength can be determined [16]. The prepared samples were poured into a four square inch moulds and puddled for 27 times per specimen with a puddling rod and then cured at $31^{\circ} \mathrm{C}\left(87^{\circ} \mathrm{F}\right)$ and $88^{\circ} \mathrm{C}\left(190^{\circ} \mathrm{F}\right)$ using thermo scientific precision 180 series water bath. The samples were cured for 12 hour and 24 hours before they were cooled and then crushed with carver model 3851 manual press. The resultant pressures were read from the pressure gauge and the compressive strengths were calculated using Equation (2).

$$
\text { Compressive Strength }(\mathrm{psi})=\frac{\text { Force }(\text { pounds })}{\text { Area }(\text { square inch })}
$$

\section{Fluid loss testing}

Fluid loss tests are conducted to establish API procedures to help determine the relative amount of fluid loss that will occur in a given cement slurry. The amount of filtrate lost by the fluid under bottomhole temperature and $6.9 \mathrm{MPa}$ (1 $000 \mathrm{psi})$ differential pressure is measured in this test [10]. A differential pressure normally exists to prevent fluid flow from the formation into the wellbore, and most formations have pore throats that are too small to allow cement particles to invade the formation. However, if a differential pressure exists into the formation, the water in the cement slurry can leak into the formation. After conditioning the slurry at the Bottomhole Circulating Temperature (BHCT) for thirty (30) minutes, the slurry was placed in the fluid cell and a differential pressure of $6.9 \mathrm{MPa}(1000 \mathrm{psi})$ was applied across the 325 mesh screen for about thirty minutes. The API fluid loss was determined using Equation (3).

$$
\text { Fluid Loss }=\frac{2 \times Q_{t} \times 5.477}{\sqrt{T}}
$$

where, $\mathrm{Q}_{\mathrm{t}}$ is the volume $(\mathrm{mL})$ of filtrate collected at the time $\mathrm{T}$ (mins) of the "blowout".

\section{Rheology testing}

According to Shahriar [17], the fundamental knowledge of oil well cement slurry rheology is necessary to evaluate the ability to remove mud and optimise slurry placement. Incomplete mud removal can result in poor cement bonding, zone communication and ineffective stimulation treatment [18]. The rheology of fluids also has a major effect on solids setting and free fluid properties and also on the friction pressures [14]. Because rheological testing is typically conducted at atmospheric pressure, the maximum temperature is limited to about $190^{\circ} \mathrm{F}[10]$. The shear stress and shear rate behaviour of slurry at different temperatures was measured in this test. The rheological properties of the fluid samples used in this study were measured using fan viscometer model 35A. The properties of interest studied included plastic viscosity $\left(\mu_{\mathrm{p}}\right)$ and yield point $\left(\tau_{0}\right)$. The plastic viscosity and the yield point value were obtained using Equations (4) and (5) respectively $[10,15,19]$.

$$
\begin{gathered}
\mu_{\mathrm{p}}(\mathrm{cp})=1.5\left(\theta_{300}-\theta_{100}\right) \\
\tau_{\mathrm{o}}\left(\mathrm{lb} / 100 \mathrm{ft}^{2}\right)=\theta_{300}-\mu_{\mathrm{p}}
\end{gathered}
$$

where $\theta_{300}$ is $300 \mathrm{rpm}$ dial reading and $\theta_{100}$ is $100 \mathrm{rpm}$ dial reading.

\section{Moisture content}

The moisture content of the cement sample was determined in accordance with API specification for drilling fluid materials [20]. 
Citation: Broni-Bediako E, Joel OF, Ofori-Sarpong G (2015) Comparative Study of Local Cements with Imported Class 'G' Cement at Different Temperatures for Oil Well Cementing Operations in Ghana. J Pet Environ Biotechnol 6: 233. doi:10.4172/2157-7463.1000233

About $10 \mathrm{~g}$ of the cement was placed in a covered container (petri-dish) of known weight $\left(\mathrm{m}_{1}\right)$ and weighed $\left(\mathrm{m}_{2}\right)$. The container containing the cement was uncovered and together with the cover was placed in an electric oven and dried at $105^{\circ} \mathrm{C}\left(221^{\circ} \mathrm{F}\right)$ for 30 minutes. The container with the cement was taken out, covered and placed in a desiccator for about 15 minutes to cool, after which it was reweighed $\left(\mathrm{m}_{3}\right)$. The moisture content (MC) of the sample was calculated as in Equation (6):

$$
\mathrm{MC}=\frac{\mathrm{m}_{2}-\mathrm{m}_{3}}{\mathrm{~m}_{3}-\mathrm{m}_{1}} \times 100
$$

\section{Results and Discussion}

\section{Thickening time analysis}

Cement placement should be of utmost concern to assure a

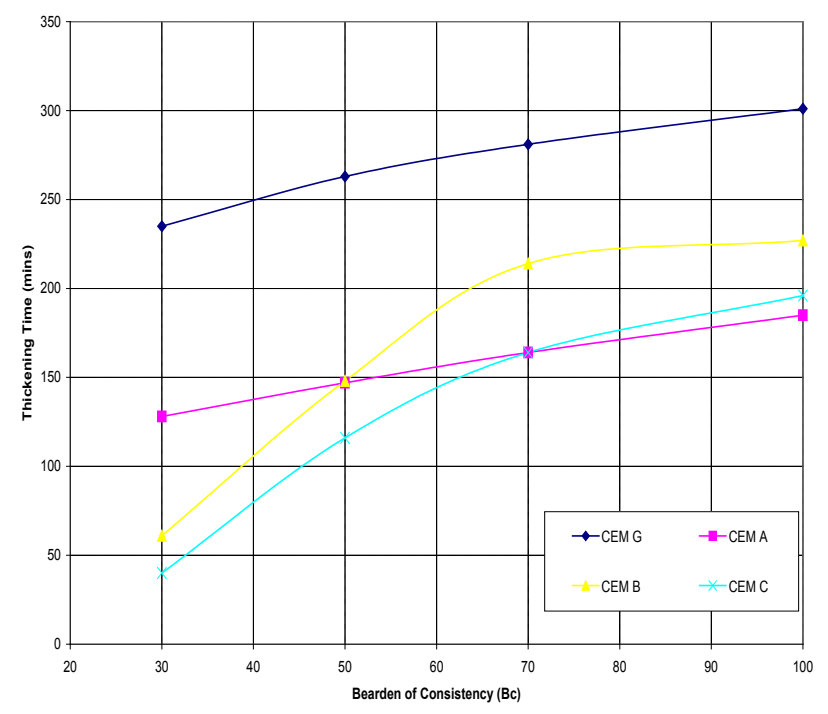

Figure 1: Thickening time vs. consistency at $27^{\circ} \mathrm{C}\left(80^{\circ} \mathrm{F}\right)$

\begin{tabular}{|c|c|c|c|}
\hline Test Condition & Units & Test 1 & Test 2 \\
\hline BHST & ${ }^{\circ} \mathrm{C}\left({ }^{\circ} \mathrm{F}\right)$ & $31(87)$ & $88(190)$ \\
\hline $\mathrm{BHCT}$ & ${ }^{\circ} \mathrm{C}\left({ }^{\circ} \mathrm{F}\right)$ & $27(80)$ & $66(150)$ \\
\hline $\mathrm{BHP}$ & MPa (psi) & $1000(6.9)$ & 7900 \\
\hline Heat Up Time & $\min$ & 13 & 53 \\
\hline \multicolumn{4}{|c|}{ Water } \\
\hline Water Type & - & Fresh Water & Fresh Water \\
\hline Water Requirement & $\begin{array}{c}\mathrm{m}^{3} / \mathrm{t} \\
(\mathrm{gal} / \mathrm{sk})\end{array}$ & $\begin{array}{c}0.45 \\
(5.07)\end{array}$ & $\begin{array}{l}0.447 \\
(5.03)\end{array}$ \\
\hline \multicolumn{4}{|c|}{ Cement } \\
\hline Cement Weight & $\%$ bwoc & 100 & 100 \\
\hline Slurry Weight & $\mathrm{kg} / \mathrm{m}^{3}(\mathrm{ppg})$ & $1893(15.8)$ & 1893 (15.8) \\
\hline Mixing Fluid & $\mathrm{m}^{3} / \mathrm{t}$ (gal/sk) & $\begin{array}{l}0.457 \\
(5.15)\end{array}$ & $0.454(5.11)$ \\
\hline Yield & $\mathrm{m}^{3} / \mathrm{t}$ (cu.ft/sk) & $\begin{array}{c}0.77 \\
(1.16)\end{array}$ & $0.77(1.16)$ \\
\hline \multicolumn{4}{|c|}{ Additives } \\
\hline Accelerator & $\%$ bwoc & 1 & - \\
\hline Defoamer & $\mathrm{m}^{3} / \mathrm{t}$ (gal/sk) & $\begin{array}{l}0.002 \\
(0.02)\end{array}$ & $\begin{array}{l}0.002 \\
(0.02)\end{array}$ \\
\hline Fluid Loss Agent & $\%$ bwoc & - & 0.5 \\
\hline Retarder & $\%$ bwoc & - & 0.18 \\
\hline
\end{tabular}

Table 1: Experimental conditions and slurry composition.

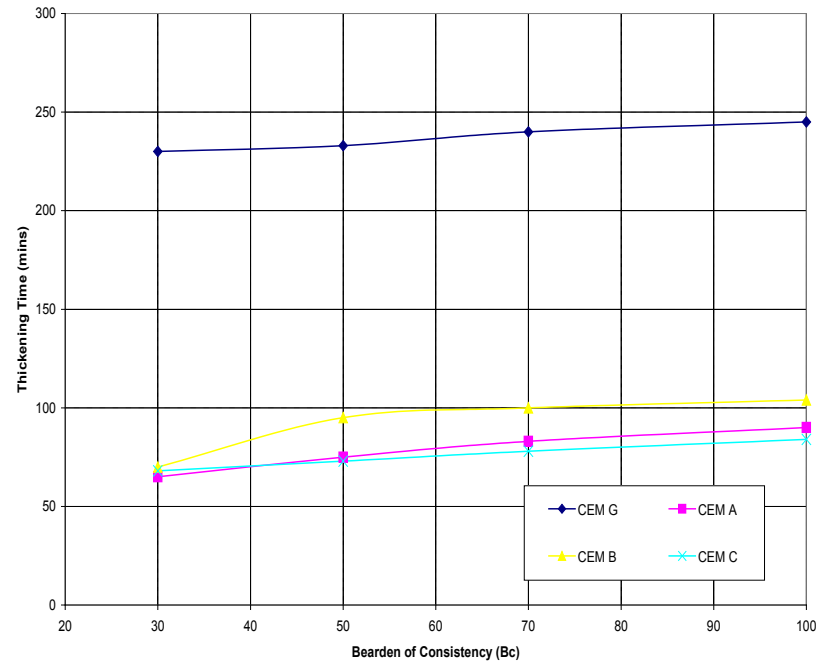

Figure 2: Thickening time vs. consistency at $66^{\circ} \mathrm{C}\left(150^{\circ} \mathrm{F}\right)$.

competent cement job. The cement should be designed with an adequate pumping time such that it can be placed downhole even in the event of a downtime due to pumping problems [22]. Figure 1 shows the results of the thickening time of the four cement samples mixed with some concentration of accelerators (Table 1) and tested at $305 \mathrm{~m}$ $(1000 \mathrm{ft}), 6.9 \mathrm{MPa}(1000 \mathrm{psi})$ and $27^{\circ} \mathrm{C}\left(80^{\circ} \mathrm{F}\right)$. From Figure 1, it could be seen that all the locally manufactured cements had shorter setting time or pumped shorter than the imported class $G$. The presence of the constituent, tricalcium aluminate $\left(\mathrm{C}_{3} \mathrm{~A}\right)$ explains why each cement sets at different times. Chemically, CEM A, CEM B and CEM C classified as local cements, have higher amounts of tricalcium aluminate and, therefore, will have higher rates of reaction during their hydration period, causing the cement slurries to set at faster or shorter times than imported cement (CEM G), which contain lower tricalcium aluminate.

The end of thickening time test was considered to be $70 \mathrm{Bc}$. At the consistency of $70 \mathrm{Bc}$, which indicates the time that cement slurry starts to set [12], the locally manufactured cements pumped shorter than the class $\mathrm{G}$ cement at a temperature of $27^{\circ} \mathrm{C}\left(80^{\circ} \mathrm{F}\right)$. CEM A, CEM $\mathrm{B}$ and CEM $\mathrm{C}$ respectively pumped 117 minutes, 67 minutes and 117 minutes shorter than the imported G. On the average, the local cements pumped 100 minutes ( 1 hour 40 minutes) shorter than the imported class G (Figure 1). However, the locally manufactured cement still appeared to be suitable for oil well cement since there are compatible with accelerator (additive) and defoamer used. Even though the local cements pumped less, they could be suitable for cementing oil wells if the operating time required for the cementing job is less or equal to the thickening time produced by the local cements. For example CEM A can be used for cementing a well if 164 minutes ( 2 hours 44 minutes) or less is required (Figure 1). Comparing the thickening time results for the local cements, CEM B pumped better than CEM A and CEM C at $70 \mathrm{Bc}$ (Figure 1).

Figure 2 shows the results of the thickening time of the four cement samples mixed with some concentration of retarder, defoamer and

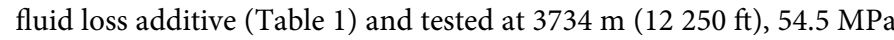
(7 $900 \mathrm{psi})$ and $66^{\circ} \mathrm{C}\left(150^{\circ} \mathrm{F}\right)$.

From Figure 2, it could be seen that the entire locally manufactured cements had shorter setting time or pumped shorter than the imported 
Citation: Broni-Bediako E, Joel OF, Ofori-Sarpong G (2015) Comparative Study of Local Cements with Imported Class 'G' Cement at Different Temperatures for Oil Well Cementing Operations in Ghana. J Pet Environ Biotechnol 6: 233. doi:10.4172/2157-7463.1000233

Page 4 of 7

class $\mathrm{G}$. At the consistency of $70 \mathrm{Bc}$, the locally manufactured cements again pumped shorter than the class $\mathrm{G}$ cement at a temperature of $66^{\circ} \mathrm{C}$ $\left(150^{\circ} \mathrm{F}\right)$. CEM A, CEM B and CEM C respectively pumped 157 minutes, 140 minutes and 162 minutes shorter than the imported G. On the average, the local cements pumped 153 minutes ( 2 hour 33 minutes) shorter than the imported class $\mathrm{G}$ (Figure 2). For very deep wells, the imported class $\mathrm{G}$ would be preferred since it is a slow reacting cement and would set longer. However, the locally manufactured cements still appeared to be suitable for oil and gas well cementing operations since they were compatible with additives used. Even though the local cements pumped less, they could be suitable for cementing oil wells if the operating time required for the cementing job is less or equal to the thickening time produced by the local cements. For example CEM A can be used for cementing a well if 83 minutes ( 1 hour 23 minutes) or less is required (Figure 2). To bring up the thickening time results of locally manufactured cements to the level of the imported class $\mathrm{G}$ cement at $66^{\circ} \mathrm{C}\left(150^{\circ} \mathrm{F}\right)$ requires that the local cement slurry is redesigned with different types of oil well additives at different concentrations. Comparing the thickening time results for the local cements, CEM B again pumped better than CEM A and CEM C at 70 $\mathrm{Bc}$ (Figure 2).

\section{Free fluid analysis}

The results of free fluid between the locally manufactured cements and imported class $\mathrm{G}$ tested at Bottom Hole Circulating Temperature (BHCT) $27^{\circ} \mathrm{C}\left(80^{\circ} \mathrm{F}\right)$ and $66^{\circ} \mathrm{C}\left(150^{\circ} \mathrm{F}\right)$ is presented in Table 2.

Generally, imported class $\mathrm{G}$ had the highest free fluid content when tested at $27^{\circ} \mathrm{C}\left(80^{\circ} \mathrm{F}\right)$ and $6.9 \mathrm{MPa}(1000 \mathrm{psi})$, making it less stable as compared to the locally manufactured cements. However, all the tested cement samples proved to have some controllable free fluid (Table 2). The higher value of free fluid content of class $\mathrm{G}$ cement could be due to poor handling which could have resulted to exposure to moisture. These results were confirmed by the moisture content of each sample as presented in Table 3 . All the cement samples proved to have no free fluid (water) when mixed with a fluid loss additive at 0.5 percent by weight of cement (\%bwoc) at a temperature of $66^{\circ} \mathrm{C}\left(150^{\circ} \mathrm{F}\right)$ and pressure of $54.5 \mathrm{MPa}$ (7 $900 \mathrm{psi}$ ) (Table 2).

\section{Fluid loss analysis}

\begin{tabular}{|c|c|c|c|c|}
\hline Cement Type & CEM G & CEM A & CEM B & CEM C \\
\hline BHCT of $27^{\circ} \mathrm{C}\left(80^{\circ} \mathrm{F}\right)$ \\
\hline Free Fluid @ 90 deg incl. (\%) & 1.3 & 0.56 & 0.2 & 0.12 \\
\hline \multicolumn{4}{|c|}{$\mathrm{BHCT}$ of $66^{\circ} \mathrm{C}\left(150^{\circ} \mathrm{F}\right)$} \\
\hline Free Fluid @ 90 deg incl. (\%) & 0 & 0 & 0 & 0 \\
\hline
\end{tabular}

\begin{tabular}{|c|c|c|c|c|}
\hline Readings $(\mathbf{g})$ & CEM G & CEM A & CEM B & CEM C \\
\hline Weight of Container $\left(\mathrm{m}_{1}\right)$ & 30.85 & 30.85 & 30.85 & 30.85 \\
\hline $\begin{array}{c}\text { Weight of Cement and } \\
\text { Container }\left(\mathrm{m}_{2}\right)\end{array}$ & 40.85 & 40.85 & 40.85 & 40.85 \\
\hline $\begin{array}{c}\text { Weight of Dry Cement and } \\
\text { Container }\left(\mathrm{m}_{3}\right)\end{array}$ & 40.72 & 40.78 & 40.79 & 40.82 \\
\hline Moisture Content $(\%)$ & $\mathbf{1 . 3 2}$ & $\mathbf{0 . 7 0}$ & $\mathbf{0 . 6 0}$ & $\mathbf{0 . 3 0}$ \\
\hline
\end{tabular}

Table 3: Moisture content of cement samples.

\begin{tabular}{|c|c|c|c|c|}
\hline Cement Type & CEM G & CEM A & CEM B & CEM C \\
\hline Fluid Loss (ml/30 minutes) & 90 & 70 & 211 & 66 \\
\hline
\end{tabular}

Table 4: Fluid loss at $66^{\circ} \mathrm{C}\left(150^{\circ} \mathrm{F}\right)$.

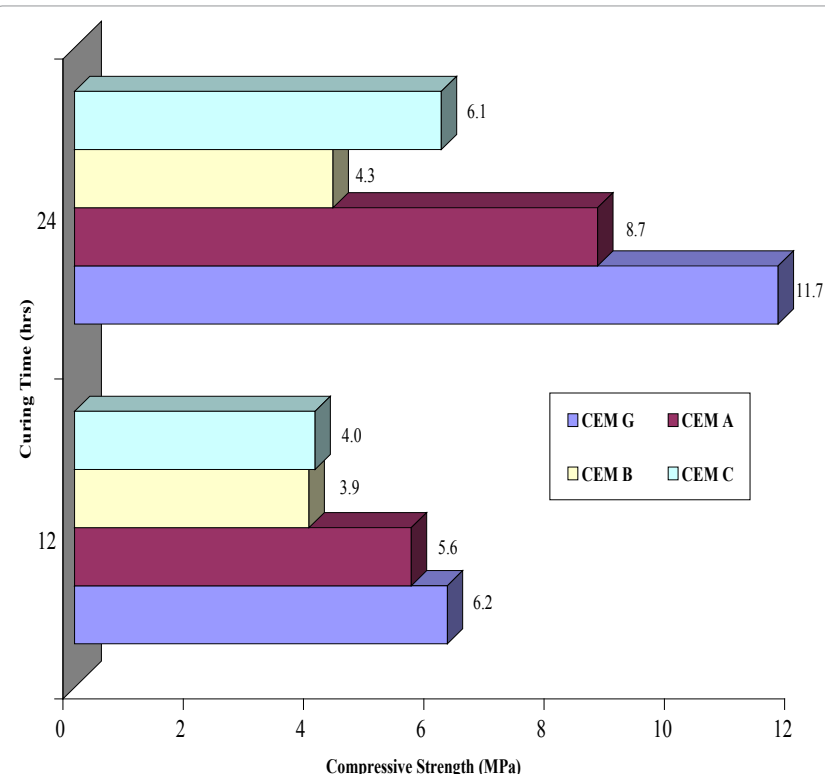

Figure 3: Compressive strength of cement cured at $31^{\circ} \mathrm{C}\left(87^{\circ} \mathrm{F}\right)$ for 12 and 24 hours.

The fluid loss of the cement should be controlled to prevent early dehydration of the slurry causing an artificial premature hardening [21]. Higher fluid loss indicates that when cement is pumped into the well, it might require secondary cementing. The fluid will escape faster from cement and cause the hole to slough [22]. In terms of fluid loss, both the imported class $\mathrm{G}$ and locally manufactured cement samples compared favourably (Table 4) as all the cements were within the recommended range posited by Anon [23].

According to Anon [24], under standard laboratory conditions (6.9 $\mathrm{MPa}$ (1 $000 \mathrm{psi}$ ) filter pressure, with a 325 mesh filter) a slurry for a squeeze job and primary cement job should give a fluid loss of 50-200 $\mathrm{cc}(\mathrm{ml})$ and 250-400 cc (ml) within thirty (30) minutes respectively. Again, the fluid loss results for all the cement samples compared favourably with the recommended values reported by Boškovic et al. [25]. According to Boškovic et al. [24], filtrate (fluid) loss for class G cement is not precisely defined by API Specification, but recommended that within thirty (30) minutes test period up to $1000 \mathrm{cc}(\mathrm{ml}), 500 \mathrm{cc}$ $(\mathrm{ml})$, less or equal to $100 \mathrm{cc}(\mathrm{ml})$ and $30-50 \mathrm{cc}(\mathrm{ml})$ respectively is vital for cementing technical casing string, production casing string, liner casing and gas wells.

\section{Compressive strength analysis}

Compressive strength of the set cements is important as it commonly represents the overall quality of cements. Higher compressive strength generally means lower porosity and increased durability [26]. Insufficient compressive strength means casing failures are more likely and the life span of the well can be dramatically reduced [27]. Result of compressive strength test cured at $31^{\circ} \mathrm{C}\left(87^{\circ} \mathrm{F}\right)$ for 12 and 24 hours for cement slurry mixed with accelerator and defoamer is presented in Figure 3 whilst the result of compressive strength cured at $88^{\circ} \mathrm{C}\left(190^{\circ} \mathrm{F}\right)$ for 12 hours and 24 hours for cement slurry mixed with a retarder, fluid loss additive and defoamer is shown in Figure 4.

At 12 hours curing periods for $\mathrm{BHST}$ of $31^{\circ} \mathrm{C}\left(87^{\circ} \mathrm{F}\right)$, the imported class $\mathrm{G}$ cement appeared to have a better strength development than all the local cements, though CEM A appeared to compare favourably with 
Citation: Broni-Bediako E, Joel OF, Ofori-Sarpong G (2015) Comparative Study of Local Cements with Imported Class 'G' Cement at Different Temperatures for Oil Well Cementing Operations in Ghana. J Pet Environ Biotechnol 6: 233. doi:10.4172/2157-7463.1000233

Page 5 of 7

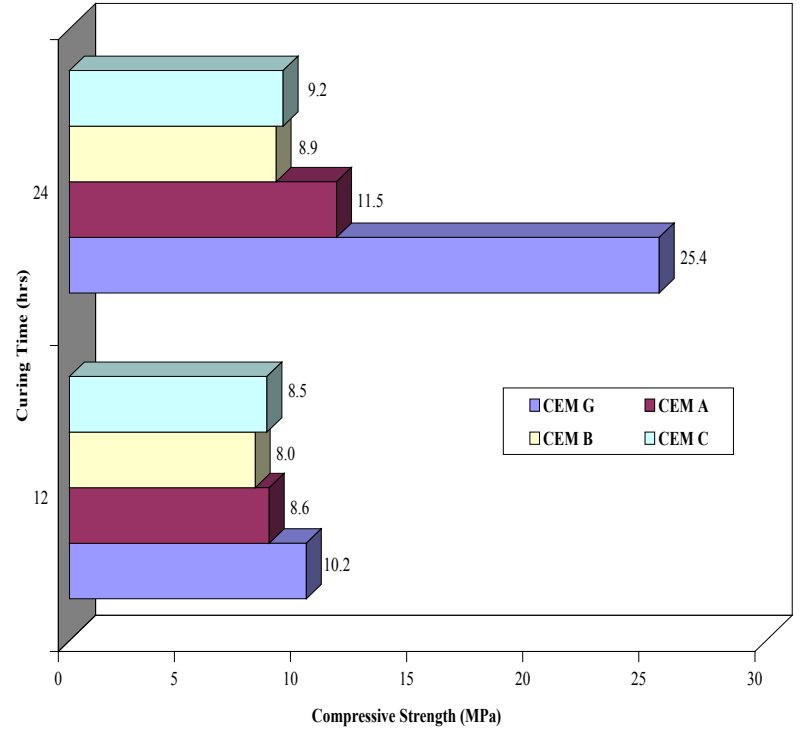

Figure 4: Compressive Strength of Cement Cured at $88^{\circ} \mathrm{C}\left(190^{\circ} \mathrm{F}\right)$ for 12 and 24 Hours.

imported class G cement. After 24 hours curing period, the imported class $\mathrm{G}$ cement again proved to have a better strength development than the locally manufactured cement (Figure 3). The difference in strength development between the local cements and class $\mathrm{G}$ could due to tricalcium silicate $\left(\mathrm{C}_{3} \mathrm{~S}\right)$. The hydration process of imported class $\mathrm{G}$ cement produced more tricalcium silicate $\left(\mathrm{C}_{3} \mathrm{~S}\right)$ which is responsible for the strength development than the locally manufactured cement. Comparing the local cements, CEM A developed better compressive strength than CEM B and CEM C.

The results for 12 hours and 24 hours curing period at BHST of $88^{\circ} \mathrm{C}\left(190^{\circ} \mathrm{F}\right)$ showed that the imported class $\mathrm{G}$ cement still had the highest strength development as compared to the locally manufactured cements (Figure 4). At 12 hours curing period the locally manufactured CEM C and CEM A compared well with the imported class $\mathrm{G}$ cement. However, at 24 hours curing period, the imported class $\mathrm{G}$ cement clearly had higher strength development than the locally manufactured cement. Again, the hydration process of imported class $G$ cement produces more tricalcium silicate $\left(\mathrm{C}_{3} \mathrm{~S}\right)$ which is responsible for the strength development than the locally manufactured cement. Comparing the local cements, CEM A developed better compressive strength than CEM B and CEM C

Generally, there is no universal agreement on strength requirement for oil well cements; however, values of 1.4 to $3.4 \mathrm{MPa}$ (200 psi to $500 \mathrm{psi}$ ) compressive strength after 24 hour curing periods are often referenced [28]. According to Sze and Kadir [29] there are generally 2 types of oil and gas cementing. One is lead slurry and the minimum compressive strength required to hold the casing is around 1.7-2.1 $\mathrm{MPa}(250-300$ psi) while for tail slurry it requires higher density and larger minimum compressive strength of $3.4 \mathrm{MPa}(500 \mathrm{psi})$ for 24 hours. However, the value of $3.4 \mathrm{MPa}$ (500 psi) is the more widely cited as the minimum compressive strength needed before drilling out or perforating a casing [16,26-29]. With reference to the most widely quoted compressive strength, the entire locally manufactured cement samples (CEM A, CEM B and CEM C) at both BHST of $31^{\circ} \mathrm{C}\left(87^{\circ} \mathrm{F}\right)$ and $88^{\circ} \mathrm{C}\left(190^{\circ} \mathrm{F}\right)$ proved to have suitable (higher) compressive strength after 24 hour curing periods to structurally hold casings. Generally, the locally manufactured cements are suitable for oil and gas well cementing in terms of its compressive strength development.

\section{Rheology analysis}

The basic reason for determination of rheological properties was to predict flow characteristics of the cement slurry using Plastic Viscosity (PV) and Yield Point (YP). The rheological values obtained from the local cement samples compared favourably with that of the imported cement at $27^{\circ} \mathrm{C}\left(80^{\circ} \mathrm{F}\right)$. In general, the problem of pumping cement slurry through wellbore occurs when plastic viscosity becomes high [29]. At a BHCT of $27^{\circ} \mathrm{C}\left(80^{\circ} \mathrm{F}\right)$, no premature gelation of cement slurry was observed for all the cement samples mixed with an accelerator and a defoamer. The plastic viscosity for all the cement samples were below $100 \mathrm{mPa} . \mathrm{s}$ (cp), which according to Abbas et al. [30] is desirable to keep cement slurry pumpable. The values of the Yield Point calculated also showed that all the slurries were pumpable at $27^{\circ} \mathrm{C}\left(80^{\circ} \mathrm{F}\right)$ (Table 5).

At a $\mathrm{BHCT}$ of $66^{\circ} \mathrm{C}\left(150^{\circ} \mathrm{F}\right)$, the imported cement appeared to be better in terms of gelation than the locally manufactured cements. CEM A and CEM C did not exhibit a thermal shock phenomenon at higher temperature $\left(150^{\circ} \mathrm{F}\right)$, however, thermal shock phenomenon was observed in rheological investigations with CEM B (Table 6).

Comparing the locally manufactured cements, CEM C and CEM A had partial stability at high temperature than CEM B. Therefore, no $\mathrm{PV}$ and YP values were obtained from the rheological deductions with the local cement CEM B. Though CEM A and CEM C experienced gelation, the gelation was not abnormal as compared to CEM B. This implies that to use the locally manufactured cement samples at high temperature $\left(\geq 150^{\circ} \mathrm{F}\right)$, additive should be added to deals with the problem of gelation. In addition, for local cements to be used effectively for cementing high temperature operations, stringent quality control during their manufacturing process is imperative.

Comparing the rheological results for all the cements, all the local

\begin{tabular}{|c|c|c|c|c|}
\hline \multirow{2}{*}{ Rheology at BHCT of $\mathbf{8 0}^{\circ} \mathbf{F}$} & \multicolumn{1}{|c|}{ CEM G } & \multicolumn{2}{|c|}{ CEM A } & \multicolumn{2}{|c|}{ CEM B } & CEM C \\
\cline { 2 - 5 } & \multicolumn{4}{|c|}{ Dial Reading } \\
\hline $300 \mathrm{rpm}$ & 58 & 104 & 99 & 81 \\
\hline $200 \mathrm{rpm}$ & 43 & 91 & 78 & 72 \\
\hline $100 \mathrm{rpm}$ & 32 & 74 & 55 & 59 \\
\hline $6 \mathrm{rpm}$ & 15 & 18 & 18 & 23 \\
\hline $3 \mathrm{rpm}$ & 10 & 16 & 12 & 18 \\
\hline Plastic Viscosity, mPa.s & 39 & 45 & 66 & 33 \\
\hline Yield Point, Pa & 9 & 28 & 16 & 23 \\
\hline
\end{tabular}

Table 5: Rheological properties of local and imported cement samples at $27^{\circ} \mathrm{C}$ $\left(80^{\circ} \mathrm{F}\right)$.

\begin{tabular}{|c|c|c|c|c|}
\hline \multirow[t]{2}{*}{ Rheology @ BHCT of $150^{\circ} \mathrm{F}$} & CEM G & CEM A & CEM B & CEM C \\
\hline & \multicolumn{4}{|c|}{ Dial Reading } \\
\hline 300 rpm & 158 & 298 & $300+$ & 255 \\
\hline 200 rpm & 125 & 240 & 246 & 207 \\
\hline $100 \mathrm{rpm}$ & 90 & 172 & 182 & 152 \\
\hline $6 \mathrm{rpm}$ & 35 & 86 & 85 & 68 \\
\hline $3 \mathrm{rpm}$ & 27 & 71 & 63 & 59 \\
\hline Plastic Viscosity (mPa.s) & 102 & 189 & - & 154.5 \\
\hline Yield Point, $\mathrm{Pa}$ & 27 & 52 & - & 48 \\
\hline
\end{tabular}

Table 6: Rheological properties of local and imported cement samples at $66^{\circ} \mathrm{C}$ $\left(150^{\circ} \mathrm{F}\right)$. 
Citation: Broni-Bediako E, Joel OF, Ofori-Sarpong G (2015) Comparative Study of Local Cements with Imported Class 'G' Cement at Different Temperatures for Oil Well Cementing Operations in Ghana. J Pet Environ Biotechnol 6: 233. doi:10.4172/2157-7463.1000233

Page 6 of 7

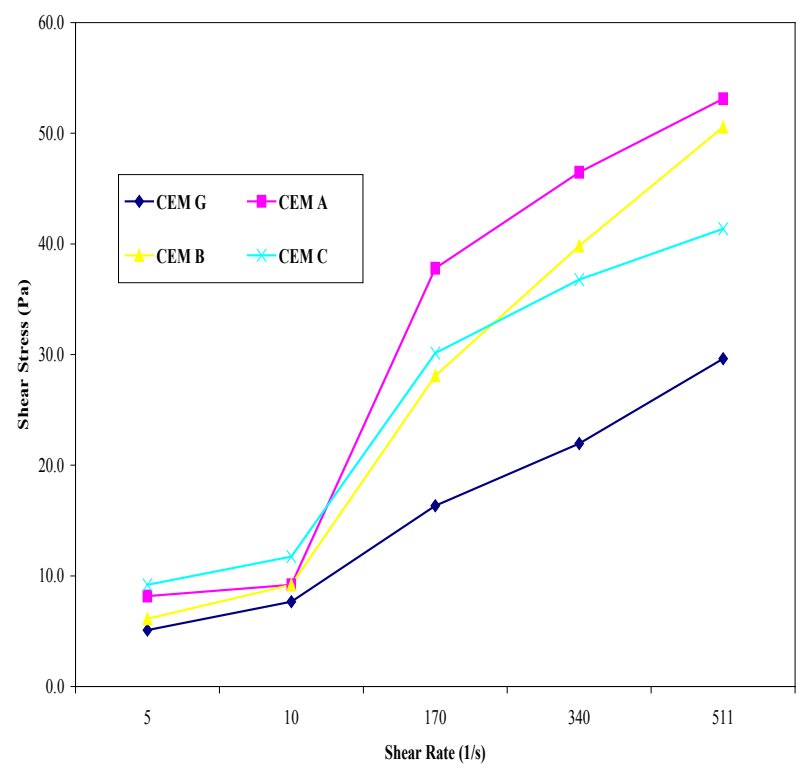

Figure 5: Shear stress vs. shear rate at $27^{\circ} \mathrm{C}\left(80^{\circ} \mathrm{F}\right)$.

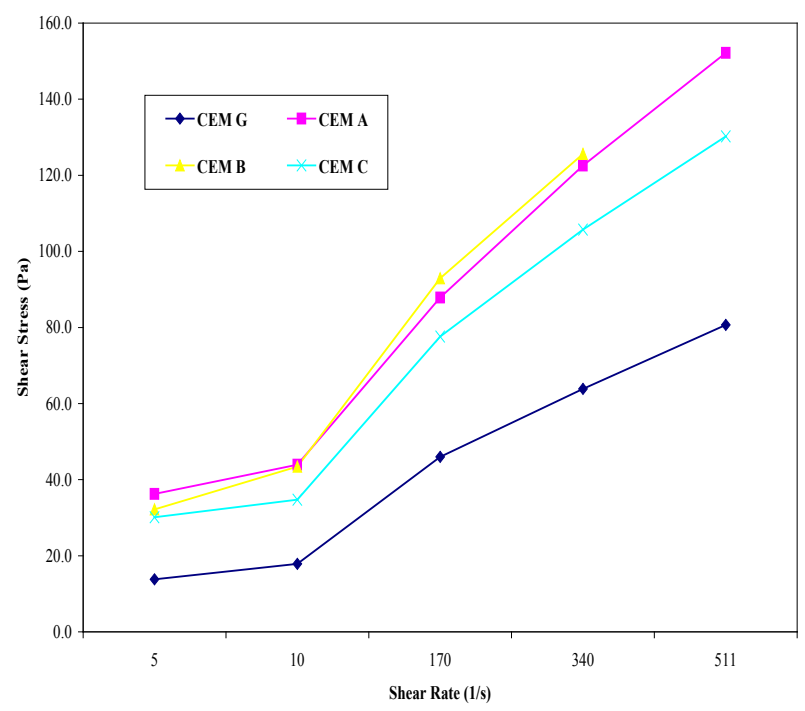

Figure 6: Shear stress vs. shear rate at $66^{\circ} \mathrm{C}\left(150^{\circ} \mathrm{F}\right)$.

cements showed higher rheological values than the imported class $\mathrm{G}$ cement at low $\left(80^{\circ} \mathrm{F}\right)$, and high temperature $\left(150^{\circ} \mathrm{F}\right)$ (Figures 5 and 6$)$.

\section{Conclusion}

From the research it could be concluded that:

a. The locally manufactured cements compared favourably with the imported Class $\mathrm{G}$ cement in terms of its compatibility with existing oil well cement additives. All the locally manufactured cements responded very well to the existing oil well additives at different temperatures.

b. The locally manufactured cements appeared to pump shorter at low $\left(80^{\circ} \mathrm{F}\right)$ and high temperature $\left(150^{\circ} \mathrm{F}\right)$. Nonetheless, at $27^{\circ} \mathrm{C}$ $\left(80^{\circ} \mathrm{F}\right)$ and $66^{\circ} \mathrm{C}\left(150^{\circ} \mathrm{F}\right)$ local cements could be used for cementing operations if operating time is less or equal to the thickening time of the local cements.

c. The locally manufactured cements samples proved to be better than the imported class $\mathrm{G}$ in terms of free fluid (water) and fluid loss at $27^{\circ} \mathrm{C}\left(80^{\circ} \mathrm{F}\right)$ and $66^{\circ} \mathrm{C}\left(150^{\circ} \mathrm{F}\right)$.

d. The entire locally manufactured cement samples proved to have the required compressive strength after 24 hour curing periods to structurally hold casings at $27^{\circ} \mathrm{C}\left(80^{\circ} \mathrm{F}\right)$ and $66^{\circ} \mathrm{C}\left(150^{\circ} \mathrm{F}\right)$. However, the imported class $\mathrm{G}$ cement appeared to have better strength development than the locally manufactured cements at both $27^{\circ} \mathrm{C}\left(80^{\circ} \mathrm{F}\right)$ and $66^{\circ} \mathrm{C}$ $\left(150^{\circ} \mathrm{F}\right)$.

e. The locally manufactured cements compared very well with imported Class $\mathrm{G}$ in terms of the plastic viscosity and yield point at low temperature $\left(80^{\circ} \mathrm{F}\right)$. However at high temperature $\left(150^{\circ} \mathrm{F}\right)$, the imported Class $\mathrm{G}$ cement proved to have better rheological values (plastic viscosity and yield point) than locally manufactured cements. Premature gelation was experienced in all the local cements at $150^{\circ} \mathrm{F}$ especially CEM B.

\section{Recommendation}

It is recommended that further test be conducted on locally manufactured cements to formulate a local substitute for imported cement samples at high temperature $\left(\geq 150^{\circ} \mathrm{F}\right)$ to deal with the premature gelation of the locally manufactured cements.

\section{Acknowledgement}

The authors are very grateful to the Management of Halliburton and POCEMA LTD, Nigeria and Mr. Anthony John of Halliburton and POCEMA Lab Staff for their immense contribution during the laboratory analysis in Port Harcourt, Nigeria.

\section{References}

1. Shahrudin S, Samsuri A, Suhiami A, Nasir AS, Ahmad Z (1993) Possibility Studies of Using Local Cement in Oil and Gas Well Cementing Operations in Malaysia, Cement Research Group, Malaysia.

2. Hodne H (2007) Rheological Performance of Cementitious Materials used in Well Cementing. University of Stavanger Stavanger, Norway.

3. Ridha S, Irawan S, Ariwahjoedi B, Jasamai M (2010) Conductivity Dispersion Characteristic of Oil well Cement Slurry during Early Hydration. International Journal of Engineering and Technology 10: 121-124.

4. Pourafshary P, Azimipour SS, Motamedi P, Samet M, Taheri SA, et al. (2009) Priority Assessment of Investment in Development of Nanotechnology in Upstream Petroleum Industry.-Society of Petroleum Engineers, Saudia Arabia Section Technical Symposium, Saudi Arabia.

5. Ershadi V, Ebadi T, Rabani AR, Ershadi L, Soltanian H (2011) Reduction of Set Cement Permeability in Oil Well to Decrease the Pollution of Receptive Environment using Spherical Nanosilica. $2^{\text {nd }}$ International Conference on Environmental Science and Technology IPCBEE Singapore 6: 101-104.

6. Nelson EB, Baret JF , Michaux M (1990) Cement Additives and Mechanism of Action. In: Nelson EB (ed.) Well Cementing. Elsevier Science Publishers, Amsterdam.

7. Ravi K, Bosma M, Gastebled O (2002) Improve The Economics of Oil And Gas Wells By Reducing the Risk of Cement Failure. International Association of Drilling Contractors/Society of Petroleum Engineers.

8. Anon (2014) Oil Well Cement.

9. Atiemo E (2012) Studies on the Effect of Selected Local Admixtures on Essential Properties of Cement for Housing Construction. University of Science and Technology, Kumasi, Ghana.

10. Anon (1997) American Petroleum Institute (API) Recommended Practice 10B for Testing Well Cements. American Petroleum Institute, Washington DC, USA. 
Citation: Broni-Bediako E, Joel OF, Ofori-Sarpong G (2015) Comparative Study of Local Cements with Imported Class 'G' Cement at Different Temperatures for Oil Well Cementing Operations in Ghana. J Pet Environ Biotechnol 6: 233. doi:10.4172/2157-7463.1000233

Page 7 of 7

11. Anon (2013) American National Standard Institute/American Petroleum Institute (ANSI/API) Specification 10A for Cements and Materials for Well Cementing API Publication Services, Washington, DC

12. Alp B, Akin S (2013) Utilization Of Supplementary Cementitious Materials In Geothermal Well Cementing Proceedings. Thirty-Eighth Workshop on Geothermal Reservoir Engineering Stanford University, California.

13. Salam KK, Arinkoola AO, Ajagbe B, Sanni O (2013) Evaluation of Thickening Time of Oil Field Class G Cement Slurry at High Temperature and Pressure using Experimental Design International Journal of Engineering Sciences 2: 361-367.

14. Joel OF (2009) The Secondary Effects of Lignosulphonate Cement Retarder on Cement Slurry Properties. Journal of Engineering and Applied Sciences 4: 1-7.

15. Falode OA, Salam KK, Arinkoola AO, Ajagbe BM (2013) Prediction of Compressive Strength of Oil Field Class G Cement Slurry using Factorial Design. Journal of Petroleum Exploration Production Technology 3: 297-302.

16. Huwel JPE, Faustino V, Roberts R (2014) Cement Compressive Strength Development Drastically Affected by Testing Procedure. Proceedings of American Association of Drilling Engineers Fluid Conference and Exhibition Houston Texas, USA

17. Shahriar A (2011) Investigation on Rheology of Oil Well Cement Slurries. The University of Western Ontario Ontario, Canada.

18. Bannister CE (1980) Rheological Evaluation of Cement Slurries Methods and Models. Society of Petroleum Engineers Annual Technical Conference and Exhibition SPE 9284 Dallas Texas, USA.

19. Darley HCH, Gray GR (1983) Composition and Properties of Drilling and Completion Fluid (6thedn.) Gulf Professional Publishing, USA.

20. Anon (2004) Specification for Drilling Fluid Material. API Publishing Service, Washington DC, USA.

21. Darbe R, Gordon C, Morgan R (2008) Slurry Design Considerations for
Mechanically Enhanced Cement Systems. Proceedings of American Association of Drilling Engineers Fluid Conference and Exhibition Houston Texas, USA.

22. Sze WH, Kadir AA (2011) The Potential of Lawin Tuff for Generating a Portland Fly Ash Cement to be used in Oil Well Cementing. International Journal of Engineering and Technology 11: 51-55.

23. Anon (2013) Cementing Lecture Notes on Drilling Engineering Department of Petroleum Engineering Heriot Watt University, UK.

24. Boškovic Z, Cebašek V, Gojkovic N (2013) Application of Local Cement for Cementing Oil Wells in the South Eastern Region of the Pannonian Basin. Arhives for Technical Sciences 8: 35-39.

25. Glatin C (2006) Drilling and Completion Prentice. Hall Inc United States of America, USA

26. Labibzadeh M, Zahabizadeh B, Khajehdezfuly A (2010) Early-age Compressive Strength Assessment of Oil Well Class G Cement due to Borehole Pressure and Temperature Changes. Journal of American Science 6: 39-47.

27. Ridha S, Irawan S, Ariwahjoedi B (2013) Strength Prediction of Class G Oil Well Cement during Early Ages by Electrical Conductivity. Journal of Petroleum Exploration Production Technology 3: 303-311.

28. Kutasov IM, Eppelbaum LV (2014) Temperature Regime of Boreholes Cementing of Production Liners Proceedings of Thirty Ninth Workshop on Geothermal Reservoir Engineering. Stanford University, California.

29. Shuker MT, Memon KR, Tunio SQ, Memon MK (2014) Laboratory Investigation on Performance of Cement Using Different Additives Schemes to Improve Early Age Compressive Strength. Research Journal of Applied Sciences Engineering and Technology 7: 2298-2305.

30. Abbas G, Irawan S, Kumar S, Memon RK, Khalwar SA (2014) "Characteristics of Oil Well Cement Slurry using Hydroxypropy Imethylcellulose. Journal of Applied Sciences 14: 1154-1160. 